$\mathrm{Y}-12$

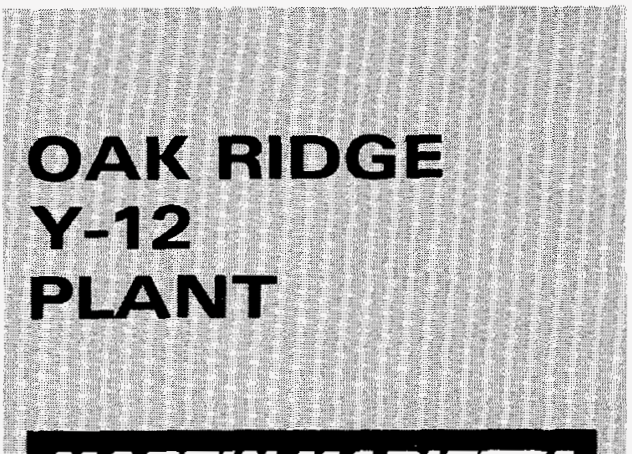

MALTIN MARIETTA

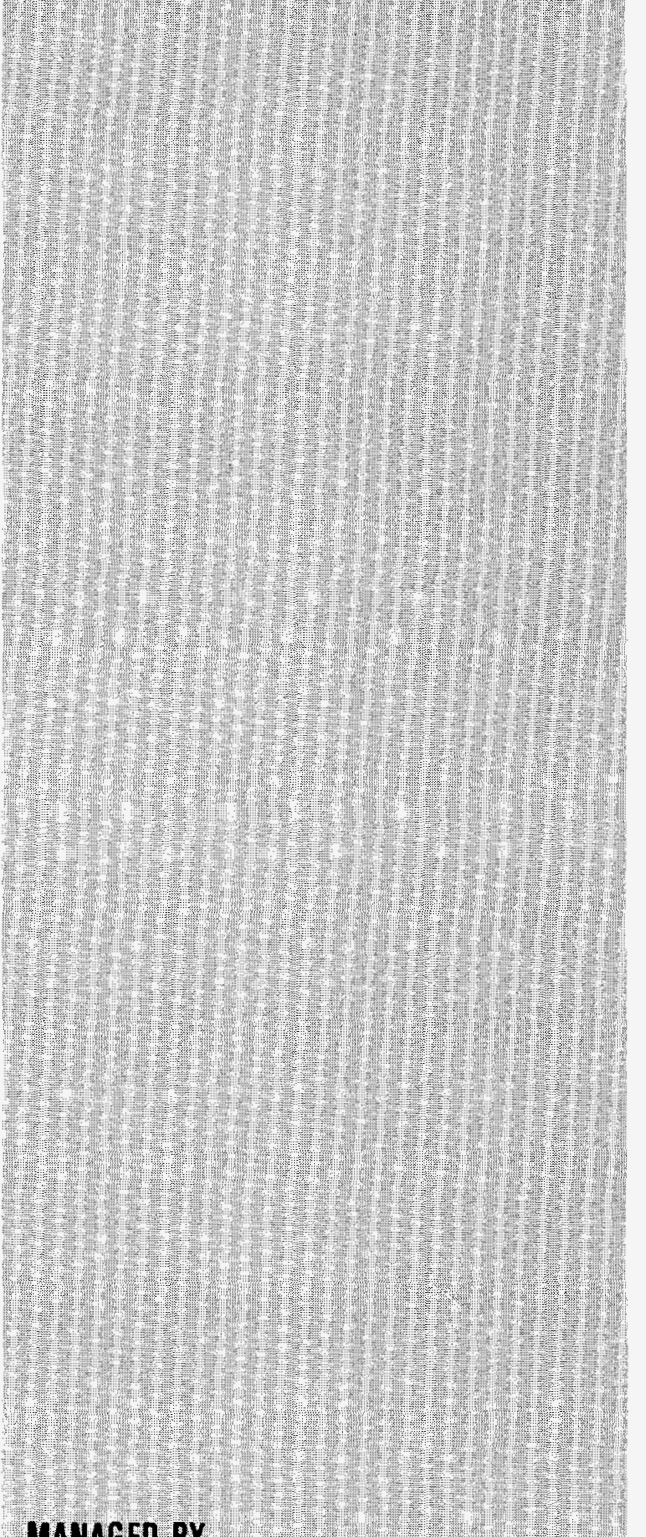

MANAGED BY

MARTIN MARIETTA ENERGY SYSTEMS, INC.

FOR THE UNITED STATES

DEPARTMENT OF ENERGY

\section{Industrial Waste Landfill IV Upgrade Package}

\author{
Prepared by \\ Martin Marietta Energy Systems, Inc. \\ Engineering Division
}

October 14, 1994

Prepared Under

Contract No. DE-AC05-84R-21400

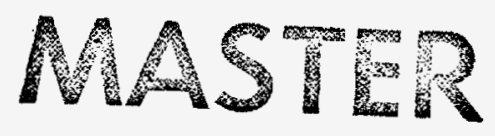




\section{DISCLAIMER}

This report was prepared as an account of work sponsored by an agency of the United States Government. Neither the United States Government nor any agency thereof, nor any of their employees, makes any warranty, express or implied, or assumes any legal liability or responsibility for the accuracy, completeness, or usefulress of any information, apparatus, product, or process disclosed, or represents that its use would not infringe privately owned rights. Reference herein to any specific commercial product, process, or service by trade name, trademark, manufacturer, or otherwise, does not necessarily constitute or imply its endorsement, recommendation, or favoring by the United States Government or any agency thereof. The views and opinions of authors expressed herein do not necessarily state or reflect those of the United States Government or any agency thereof. 


\section{DISCLAMERR}

Portions of this document may be illegible in electronic image products. Images are produced from the best available original document. 


\section{ATTACHMENT B}

THE FOLLOWING ARE PAGES TO BE REPLACED, DELETED, OR ADDED

Y/WM-187:

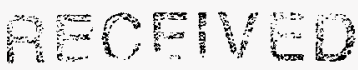

Main Document Cover Page to replace the old page

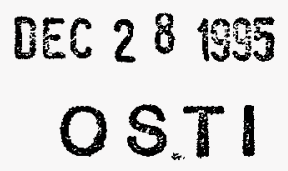

Y/TS-399/R1, "DESIGN AND OPERATING PROCEDURE FOR THE Y-12 INDUSTRIAL WASTE LANDFILL IV:

Cover Page to replace the old page

Page 9 to replace Page 9

Page 15 to replace Page 15

Delete Appendix D

Specification Sections of YIWM-187:

Table of Content to replace the old page

Page 02220-8 to replace Page 02220-8

Page 02598-8 to replace Page 02598-8

Page 02598-12 to replace Page 02598-12

Design Drawing:

C2E-900000-A034 Rev A to replace C2E-900000-A034 Rev 0

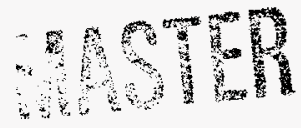


Y/TS-399/R2

\section{DESIGN AND OPERATING PROCEDURE FOR THE Y-12 INDUSTRIAL LANDFILL IV}

Date of Revision: September 1994

Oak Ridge Y-12 Plant

Oak Ridge, Tennessee 37831-8169 managed by

Martin Marietta Energy Systems, Inc. for the

U. S. DEPARTMENT OF ENERGY under contract DE-AC05-840R21400 
220 feet segment as shown on Drawing C2E900000A034.

\section{Proposed Landfill Development}

Further development of the IWLF-IV disposal areas will be sequenced as shown on Drawing C2E900000A034, and the section and details shown on Drawing C2E900000A036. The development of each disposal area will occur so as to promote drainage of runoff away from the working face. Temporary roads will be built as each area is developed. They will be located such that at least one road is available for traffic into a working face that can be accessed during all weather.

The excavations will not exceed 35 feet for that part of the site above the elevation of 1180 feet and will not extend below the elevation of 1160 feet. Excavations will not exceed 25 feet for that part of the landfill between 1140 and 1180 feet and there will be no excavations for landfilling below the elevation of 1140 feet.

The proposed final contours, shown on Drawing C2E900000A035, create a small, relatively flat top area with a five percent slope and a maximum elevation of approximately 1200.5 feet. The closed landfill will slope downward from this flat top with a minimum of four percent and a maximum of 3:1 side slopes.

\section{Seismic Analysis}

A site-specific seismic study entitled "Seismic Hazard Evaluation for the DOE Oak Ridge Reservation" (document Y/EN-4683) has been submitted to TDEC for review. The site-specific study indicates that the maximum horizontal acceleration at the site is $0.068 \mathrm{~g}$ with an annual exceedance probability of 0.2 percent in 500 years. The site study results for horizontal acceleration are less than the regulatory requirement of $0.1 \mathrm{~g}$ with an annual exceedance of 10 percent in 250 years. Therefore the landfill does not reside in a seismic impact zone. With consideration for the referenced site-specific seismic study, it will not be necessary to address seismic design for the landfill components in the Landfill $I V$ permit documents.

\section{Soil Balance and Cover Material}

All soil cover material to be used for the IWLF-IV, for both Area 1 and Area 2, is available on-site (i.e. East Borrow Area, West Borrow Area, Industrial Landfill V, Construction/Demolition Landfill VI, and Construction/Demolition Landfill VII). The total soil requirement for the entire IWLF-IV cover is estimated to be 52,203 cubic yards (includes daily, intermediate, and final soil cover). The landfill will be an area fill operation. Detailed plans of the landfill construction are provided in the drawings.

In order to develop Area 2, excavation will begin on the toe of the permanent berm and progress westward. The site will be excavated in stages to minimize land disturbance, control erosion and minimize leachate bed infiltration from stormwater flow. There will be an access/drainage way which will extend to the west end of the site from the working face.

Both areas of the landfill will operate concurrently and solid waste disposed of in the IWLF-IV will be covered at the end of each day with a minimum of $6^{\prime \prime}$ of soil. If deliveries become infrequent and cause covered surfaces to be exposed for more than $\mathbf{3 0}$ days, an intermediate cover of 12 inches will be used in lieu of daily cover of 6 inches.

Upon fill of the entire landfill grade, final cover will be placed. Final cover will be applied to minimize infiltration of precipitation into the waste, to provide a pleasing appearance, and to provide a growing surface for vegetation. Final cover on the side slopes and landfill top will consist of 42 inches of soil that includes a 24 inch compacted, low permeability layer, $\left(1 \times 10^{-7}\right.$ centimeters per second or less) placed over the waste and overlain by a 30 or more mil FML, followed by a geonet, then a geotextile fabric and an 18 inch protective layer of soil that will support vegetative growth. Placement of the final cover will be according to procedures outlined in the construction quality assurance/quality control (CQC) plan. 
A sign is located at the facility which can be viewed at both entrances and will provide the following information:

1. Facility Name

2. Emergency Phone Numbers

3. Restricted Users

4. Permitted Users

5. Standard Operating Hours

\section{Equipment}

The Principal pieces of equipment used at the landfill will include:

1. Landfill compactor.

2. Endloader for compaction and cover.

3. Scraper for providing cover materials.

4. Second endloader as backup to the endloader for compaction and cover.

5. Water trailer for dust control.

Other support equipment available for use at the site includes graders, dump trucks and bulldozers. Replacements for equipment are scheduled and procured with capital funds as approved by the DOE.

\section{Placement of Waste Material}

All waste material is subject to analysis under the Radioactive and Hazardous Constituents Screening Plan for Industrial Waste Landfill IV (Y/IA-215/Rev. 1). If the waste is acceptable for disposal at IWLF IV the collection vehicles will enter the site from the West Patrol Road or Old Mt. Vernon Road and unload the waste on the working face of the landfill as directed by the landfill operator. The waste is unloaded and placed on the working face in a confined area. The volume of in-place compacted waste and soil cover as constructed for each disposal shall constitute a cell. The top surface of the cell will be approximately square to facilitate compaction and to minimize the cover material required at the end of the day. The actual dimensions of a cell depends upon the waste received on any given day. Access roads from the perimeter road to the working face shall be moved or modified as required for proper operations. Personnel will immediately pick-up any liter scattered during disposal.

Before initial placement of waste, windows (minimum 3'x 3') shall be cut through the protective soil layer to expose the geotextile filter fabric. A rubber tired backhoe, tracked highlift or similar equipment will excavate the windows. The geotextile filter fabric will then be cut several times with a knife or removed to enhance leachate flow to the gravel drainage and leachate pipe collection system. No. 57 stone will be placed in the window excavation (approximately 12 inches thick) prior to placement and compaction of waste in the cell. The cutting of windows and backfilling with No. 57 stone will be repeated on successive horizontal layers of protective cover as waste cells are placed within the landfill.

During placement of the initial waste layer, equipment and vehicles will utilize long radius tums and operate in a "straight line manner" to the extent possible to protect the undertying leachate system and geomembrane from damage.

\section{Cover Materiak}

Soil obtained during trench excavation, along with soil from the East Borrow Area, West Borrow Area, Industrial Landfill V, Construction/Demolition Landfill VI, and Construction/Demolition Landfill VII will be used as daily, and final cover for the compacted solid waste. Any soil stockpiled at the landfill will be contoured and seeded to minimize erosion. A minimum of twelve inches of compacted clay soil, will be distributed on the exposed edges of the solid waste at the end of each operating day. A landfill compactor or endloader will be used to spread and compact the cover material. Intermediate cover will be applied as the final lifts are completed. The top of the final cover will consist of a 18 inch vegetative cover to prevent erosion and surface deterioration. Sandwiched between the vegetative and the covered waste from the top down is a geotextile fabric, a geonet for drainage, a $\mathbf{3 0}$ mil or greater polyvinyl FML, and 24 inches of compacted clay. Side slopes will be maintained 


\section{DIVISION 2 - SITE WORK}

SITE WORK

CONTENTS

SECTION NO.

PAGE NO.

* 02220

Excavating, Backfilling and compacting 02220-1

02223

Excavating, Backfilling and compacting 02223-1

for structures

02225

Excavating, Backfilling and Compacting 02225-1 for Utilities

02270

02276

Slope Protection and Erosion Control

02270-1

Geotextile Filter Fabric

$02276-1$

02505

Stabilized Aggregate Base Course

$02505-1$

Synthetic Liner

$02598-1$

Leachate and Sanitary Manholes

$02605-1$

Leachate Pipe System

02610-1

02610

Storm Drains

$02720-1$

02720

Seeding

02936-1

* These sections have been revised and changes are shown in italics on pages listed below:

Section 02220, page 02220-8, Rev. 1, September 30, 1994

Section 02598, page 02598-8, Rev. 1, September 30, 1994

Section 02598, page 02598-12, Rev. 1, September 30, 1994 
previous compacted lift shall be scarified with a disk to a minimum depth of 1 inch to ensure good bonding between lifts.

\subsection{GRANULAR DRAINAGE LAYER}

After the geomembrane, geonet and geotextile layers have been placed on the compacted clay liner, a twelve inch thick granular drainage layer shall be placed on the bottom of the landfill. The granular material shall be placed in a manner to preclude damage to the geosynthetic layers. Low ground pressure equipment, wide tracked shall be used to distribute the granular material over the geosynthetic layers. Pneumatic tired equipment shall not be used. Wide tracked equipment shall be no larger than a $D-4$ or $D-5$ dozer.

A minimum of twelve inches of granular drainage material shall be kept between the equipment tracks and the uppermost geotextile layer at all times. To the extent possible tracked equipment shall be operated in a straight line manner.

\subsection{PROTECTIVE SOIL COVER}

A twelve inch thick protective soil cover layer shall be placed on the bottom and side slopes of the landfill after the geotextile has been placed on the drainage layer. The protective soil cover shall be placed in one loose lift, spread to a uniform thickness while maintaining a minimum of 12 inches of soil between the construction equipment and the geotextile. Low ground pressure equipment, wide tracked shall be used to distribute the material over the geotextile. The material shall be compacted with a smooth steel drum roller to prevent damage to the geotextile. Equipment shall utilize long radius turns while placing and compacting the protective soil cover.

END OF SECTION

Specification Section 02220

Excavating, Backfilling \& Compacting Rev. 1, September 30, 1994 
Extreme care should be taken throughout the work to avoid fishmouths, wrinkles, folds or pleats in the seam area. Where fishmouths do occur, they should be slit out far enough from the seam to dissipate them, lapped, seamed together in the lapped area and patched.

If field seams are made using the hot wedge thermal fusion technique, a test seam, approximately $6 \mathrm{ft}$. long shall be made prior to production seaming. The test seam shall be tested for bonded seam strength in accordance with ASTM D751, and peeI adhesion in accordance with ASTM D413 (machine method). The minimum acceptable value for the bonded seam strength test is 200 pounds/inch width. The minimum acceptable value for the peel adhesion test is 30 pounds/inch width. Production seaming shall then be performed using the same machine setting as for the test seam.

Test seams shall be made at least twice per day or whenever there is a major change in the weather conditions. Test seams shall be made by each seamer prior to using each seaming machine, or whenever a machine has been shut down and restarted.

c. Joints to structures

Securing the lining to structures shall be in accordance with those details shown on the drawings submitted by the Contractor and approved by the Construction Manager.

D. Repairs to the Liner

Any necessary repairs to the liner shall be patched with the liner material itself. Use a patch with rounded corners, large enough to extend 6 inches in all directions from the puncture. Apply as above for lap joints.

E. The Contractor shall furnish a sufficient number of temporary anchors to prevent damage to the liner due to wind or other forces. The liner shall be secured at all times to hold it down during high winds.

\subsection{QUALITY ASSURANCE}

A. Shipping and storage of Liner Material

The liner material shall be kept dry and out of direct sunlight until installation.

B. Liner Repairability

The liner material must be repairable. This will require welding new liner panels to the then aged liner panels installed by this contract. Therefore, the panels must be weldable (fusible) in the future. The contractor shall certify that this will be possible and submit a procedure for liner repairs. 
manufacturer's or supplier's testing laboratory shall not be accepted for compliance with these specifications. Failed seams shall be recorded as to location and seaming crew. The data should be reviewed for possible patterns. Repairs should be made in accordance with approved techniques and retested to verify their integrity. Any doubtful areas shall be tested with a vacuum seam tester or other device as approved by the Construction Manager.

G. All field seams and repair patches shall be tested using a vacuum box at a negative pressure of $5 \mathrm{psi}$. A Geomembrane Installation Inspection Report, with signoffs, shall be maintained.

H. One test coupon must be taken from the interior portion of each field seam to provide sufficient material and seam length for destructive testing by an independent laboratory for bonded seam strength in accordance with ASTM D751, and peel adhesion in accordance with ASTM D413 (machine method). The field sample shall be taken at the same time the field seam is being constructed. The minimum acceptable value for the bonded seam strength test is 200 pounds/inch width. The minimum acceptable value for the peel adhesion test is 30 pounds/inch width. Field samples shall be forwarded to the laboratory on the same day they are prepared.

If a seam test fails, an additional test specimen shall be prepared from the same coupon as the failed test specimen. If the retest fails to achieve adequate strength, the construction Manager shall be notified and a suitable remedy shall be determined.

End of section

Except for Attached Exhibit
Specification Section 02598

Synthetic Liner

$02598-12$ 


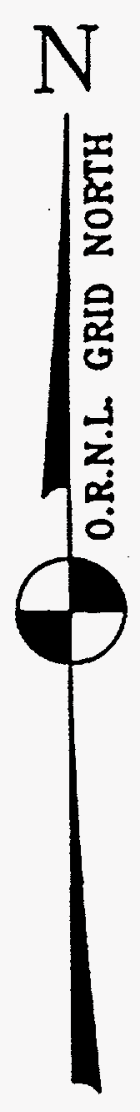

$\frac{8}{6}$

옹

N 28800

N 28700

$+$

10' $\times 30^{\prime}$ PAD
(FUTURE)

(FUTURE)

$25^{\prime} \times 37^{\prime}$ INSIDE

CONTAINMENT AREA

T.W. EL. 1181.0

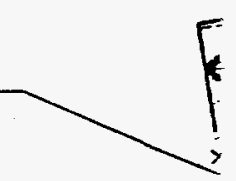


음

กิ์

8
กิ
ก

옹

w

w

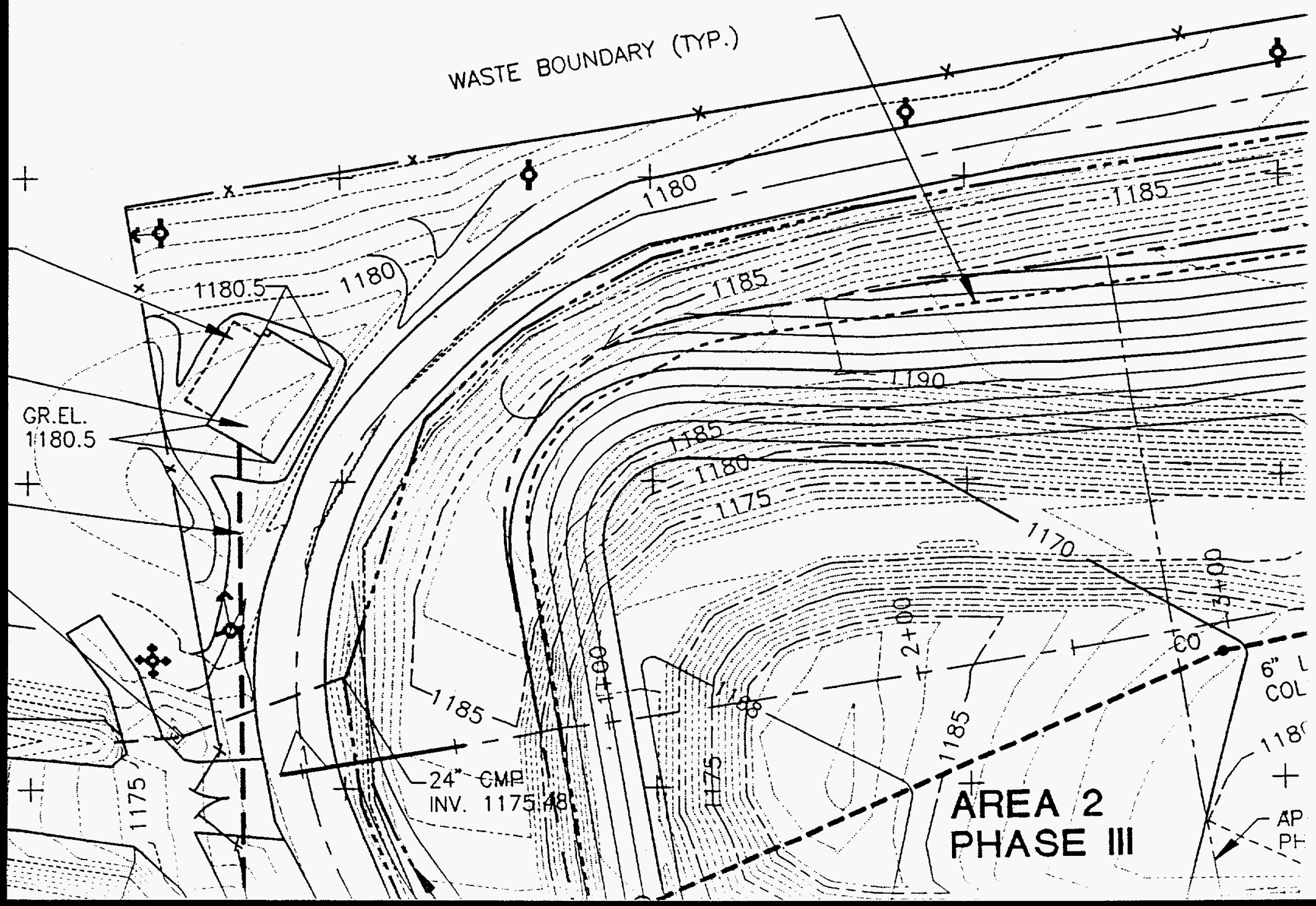




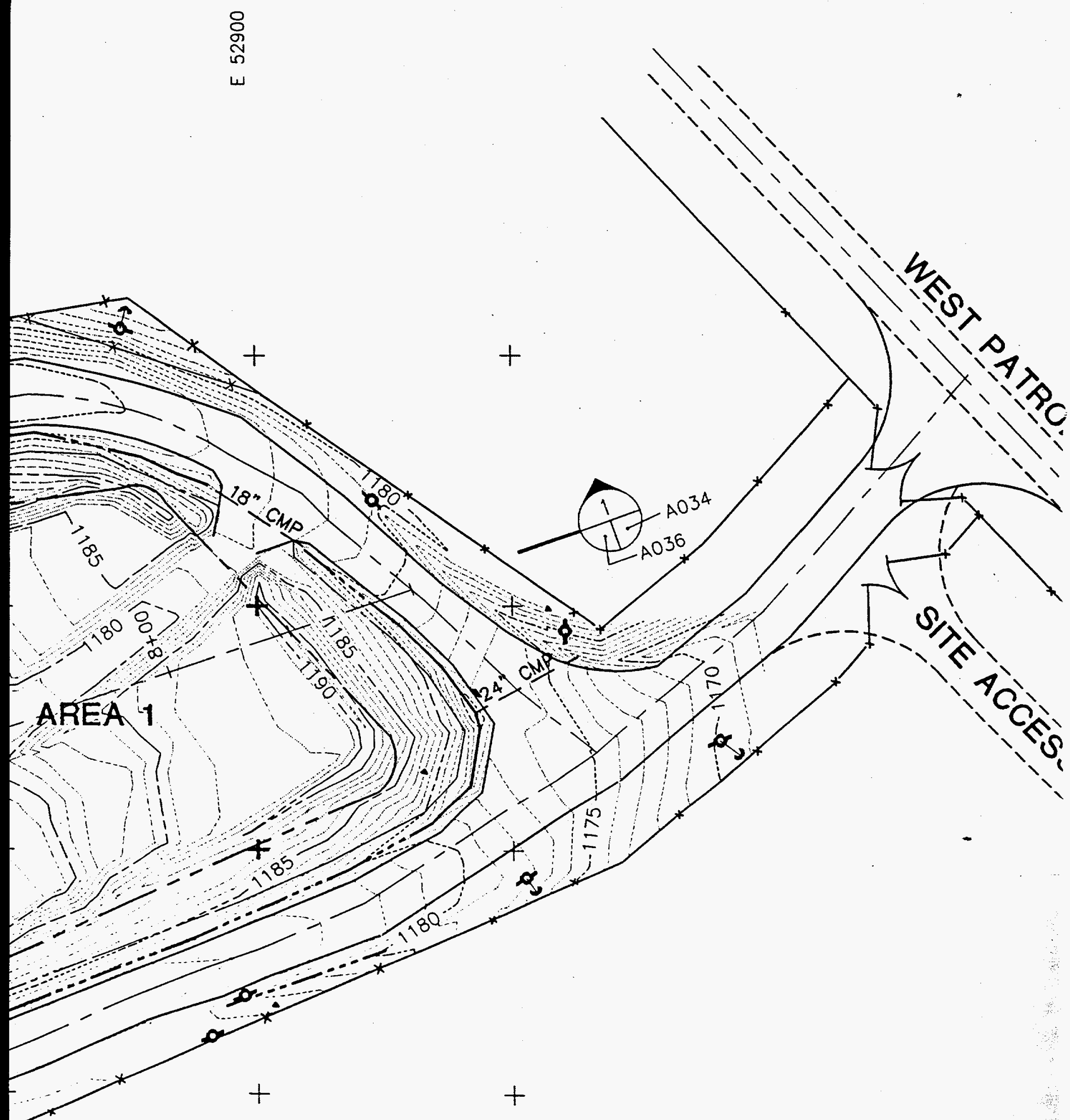




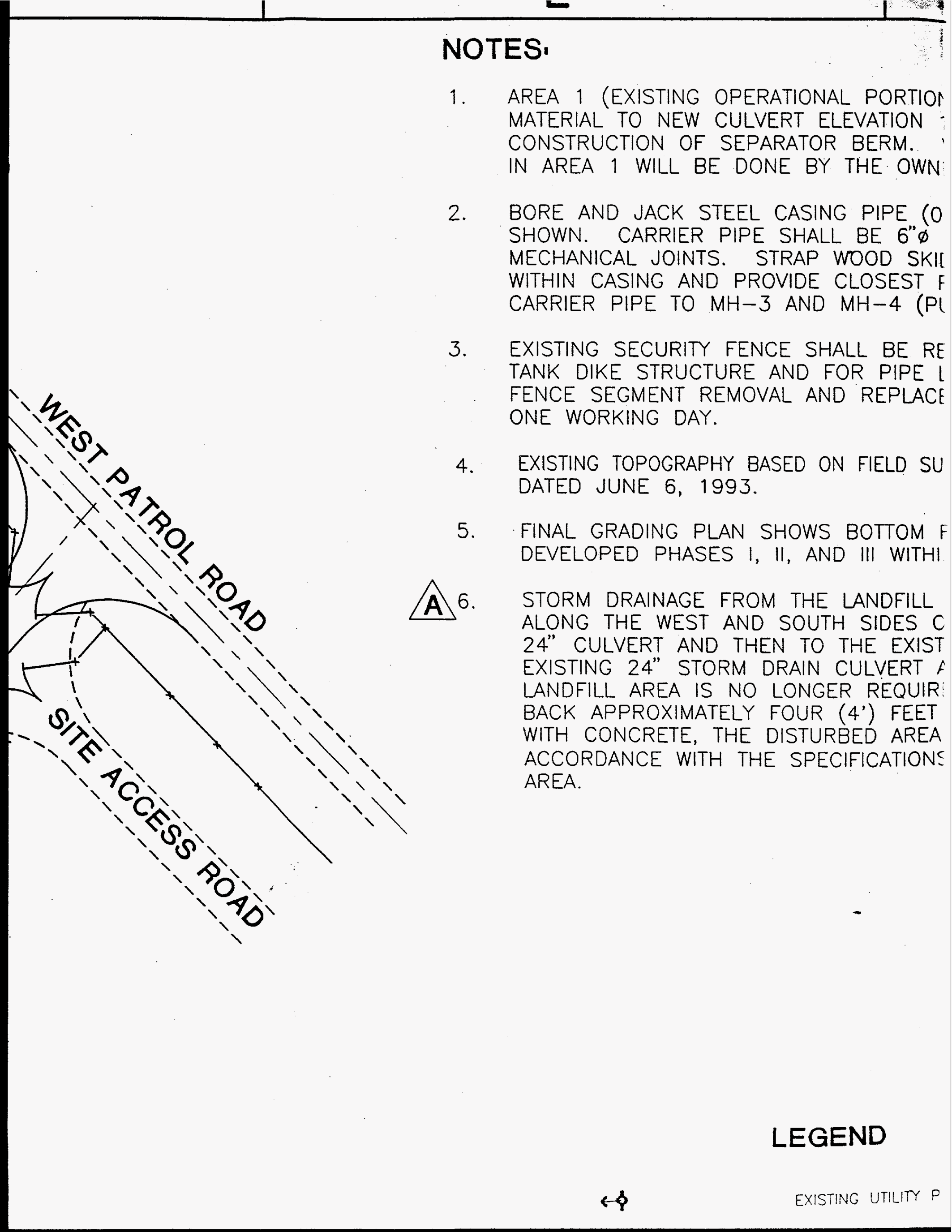


(EXISTING OPERATIONAL PORTION) WILL BE FILLED WITH WASTE AND COVER TO NEW CULVERT ELEVATION 1183.0 PRIOR TO COMPLETION OF JCTION OF SEPARATOR BERM. WASTE AND COVER FILLING OPERATIONS 1 WILL BE DONE BY THE OWNER.

ND JACK STEEL CASING PIPE (0.31" THK.) UNDER ROAD WITHIN LIMITS CARRIER PIPE SHALL BE 6" $\varnothing$ DUCTILE IRON PIPE, CLASS 51 WITH ICAL JOINTS. STRAP WOOD SKIDS ON CARRIER PIPE TO CENTER CASING AND PROVIDE CLOSEST POSSIBLE FIT. EXTEND DUCTILE IRON PIPE TO MH-3 AND MH-4 (PUMP STATION).

SECURITY FENCE SHALL BE REMOVED AND RESET FOR GRADING AT KE STRUCTURE AND FOR PIPE LINE EXCAVATIONS AS REQUIRED. SEGMENT REMOVAL AND REPLACEMENT MUST BE COMPLETED WITHIN RKING DAY.

TOPOGRAPHY BASED ON FIELD SURVEY BY ADAMS CRAFT HERZ WALKER JUNE $6,1993$.

GRADING PLAN SHOWS BOTTOM FINISH GRADES FOR FULLY

PEDD PHASES I, II, AND III WITHIN THE AREA 2 PORTION OF LANDFILL IV.

DRAINAGE FROM THE LANDFILL SITE WILL BE DIRECTED TO A DITCH THE WEST AND SOUTH SIDES OF THE ACCESS ROAD TO AN EXISTING ULVERT AND THEN TO THE EXISTING SEDIMENT BASIN. WHEN THE IG 24" STORM DRAIN CULVERT AT THE SOUTHWEST CORNER OF THE LL AREA IS NO LONGER REQUIRED FOR DRAINAGE, IT IS TO BE CUT APPROXIMATELY FOUR (4') FEET INTO THE EMBANKMENT, PLUGGED OONCRETE, THE DISTURBED AREA BACKFILLED AND COMPACTED IN DANCE WITH THE SPECIFICATIONS PRIOR TO WASTE PLACEMENT IN THIS

\section{LEGEND}




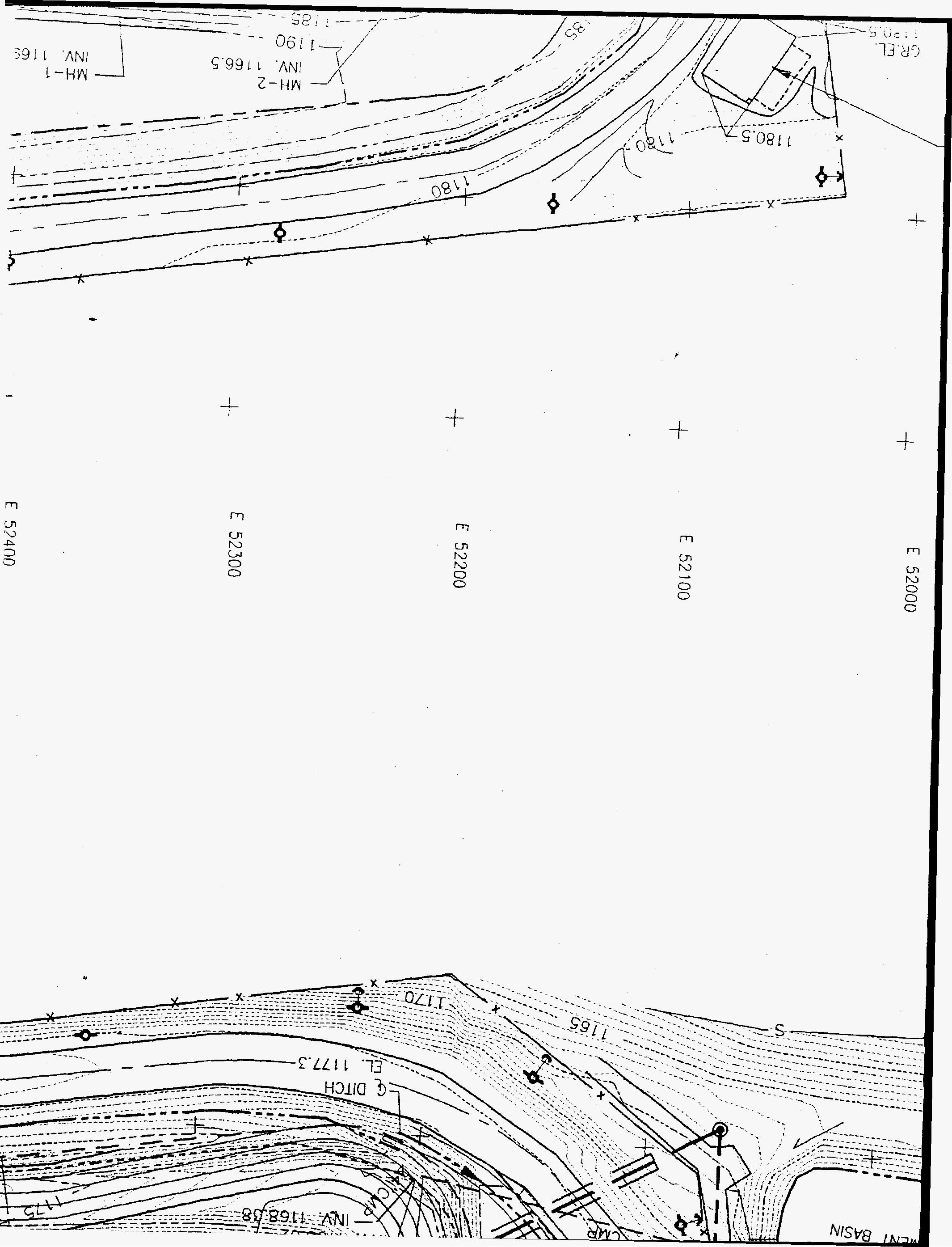


$+$
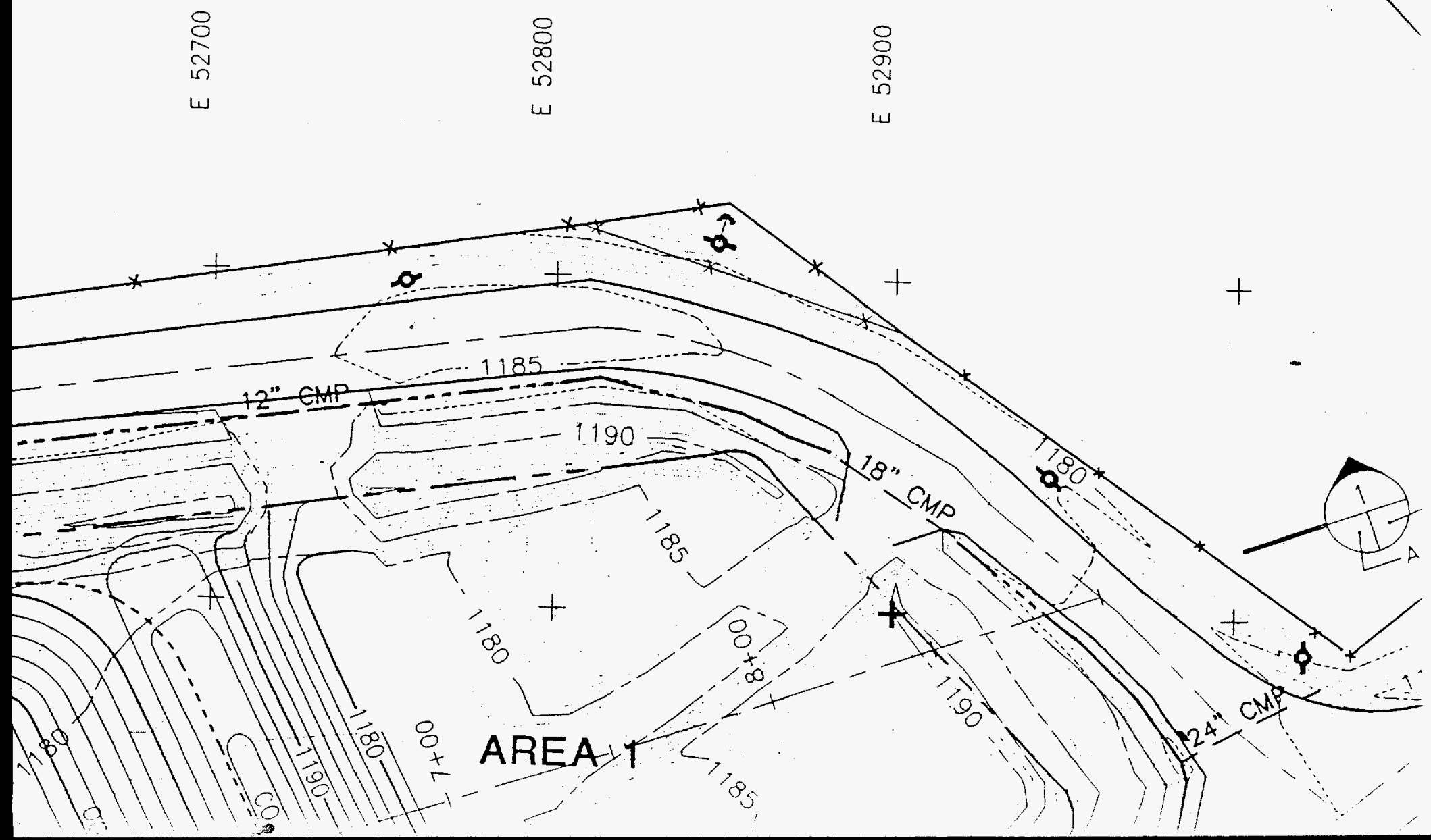
EXISTING FENCE

$-24^{\prime \prime} \underline{C M P}$ $-\cdots$

EXISTING CULVERTS

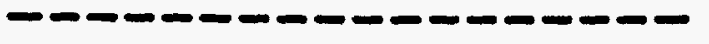

LEACHATE COLLECTION PIPE (PERFORATED)

- - - - - - - NEW FORCE MAIN

$\longrightarrow-\longrightarrow-$ LEACHATE COLLECTION PIPE

FUTURE LEACHATE COLLECTION PIPE (PERFORATED)

$-\longrightarrow-$ MANHOLE

$-\overline{15} \overline{0}$. NEW CULVERT

$-\cdots$

CONTROL LINE

GW -521

(i) ${ }^{6 W-217}$

MONITORING WELLS

$0^{8-1}$

BORINGS

$\mathrm{OITCH}$

LIMITS OF RIP-RAP

WASTE BOUNDARY 
$x-x-$ EXISTING FENCE

$P$

- - - - EXISTING CULVERTS

LEACHATE COLLECTION PIPE (PERFORATED)

- - - - NEW FORCE MAIN

- - Leachate Collection PIPE

FUTURE LEACHATE COLLECTION PIPE (PERFORATED)

S-

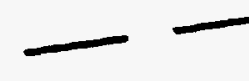

MANHOLE

NEW CULVERT

$\overline{15 \pi \varnothing}$

CONTROL LINE

GW-217

(i⿶)

MONITORING WELLS

BORINGS

$\mathrm{DITCH}$

LIMITS OF RIP-RAP

WASTE BOUNDARY 

LEACHATE STORAGE TANKS

N 28500

MODIFY EXISTING SEDIMENT

N 28400 BASIN RISER PIPE. SEE DETAIL

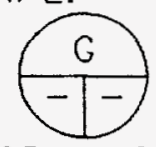

$\mathrm{AO} 34$ A037

NO REPRESENTAIION OR WARRANTY, EXPRESSED OR MPUED, IS MADE AS TO THE ACCURACY, COMPLETENESS OF USEFUUNESS OF THE INFORMATION OR STATEMENTS CONTANED IN THESE DRAWINGS. OR THAT THE USE OR OISCLOSURE OF ANY INFORUATION. APPARATUS, METHOO OR PROCESS DISCLOSEO AN MHESE DRAMMCS MAY NOT INFRINGE PRIVATE RIGHTS OF OTHERS. NO UABUTY IS ASSUMED MTH RESPECT TO THE USE OF, OR FOR OAMACES RESULTING FROM THE USE OF NNY INFORMATION. APPARATUS METHOD OR PROCESS DISCLOSEO IN THESE ORAWINGS. DRAKMNGS MAOE AVALABLE FOR INFORMATION TO BIDOER ARE NOT TO BE USEO FOR OTHER PURPOSES, ANO ARE TO BE RETURNED UPON REOUEST OF THE FORMAROING CONTRACTOR.
THIS DRAWING

PRODUCED ON AUTOCA $D O$ NOT REVISE MANL

THIS DOCUMENT CONT. CHANGE CDNTROL SYS ENGINEERING PRDCEDL 


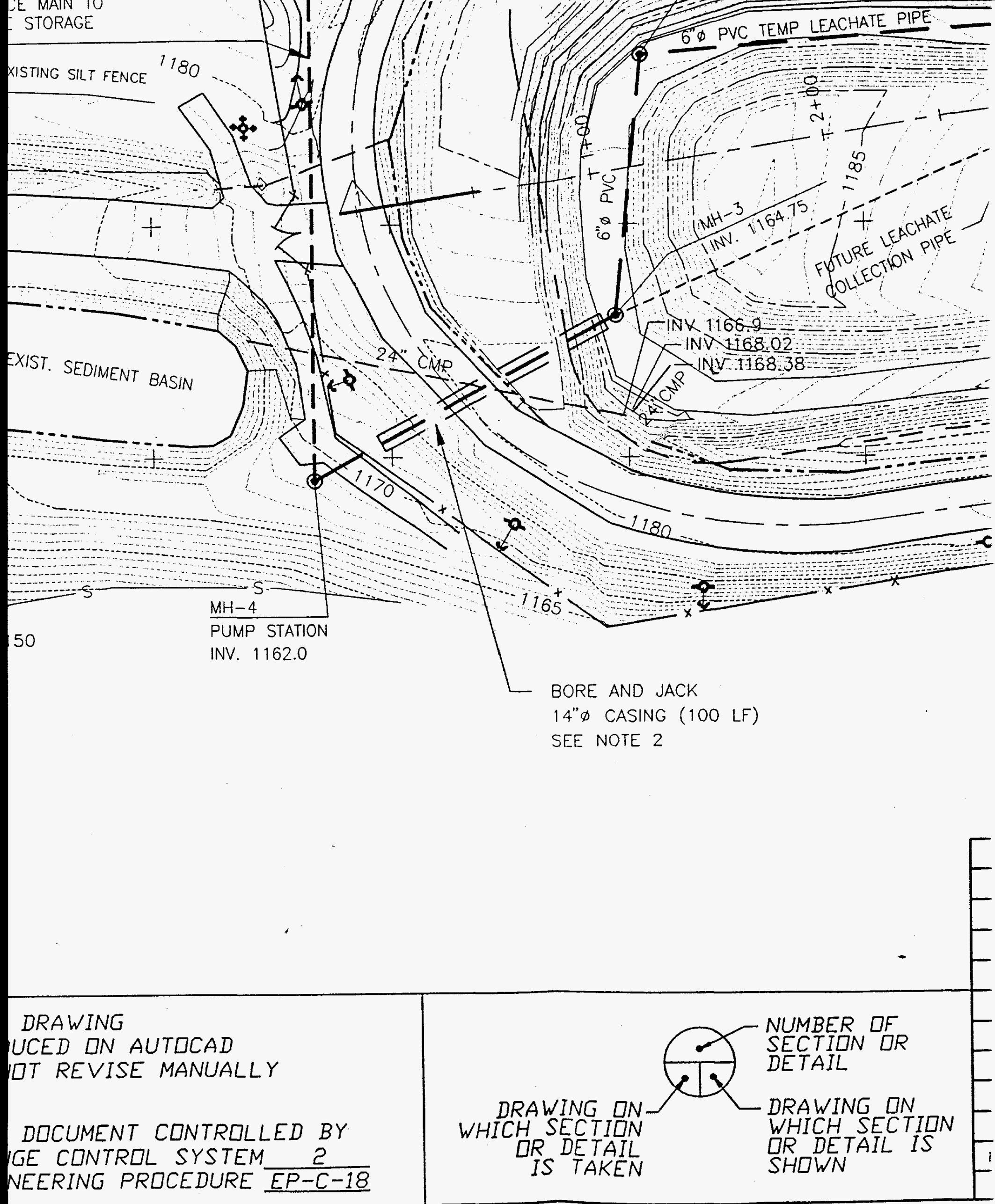




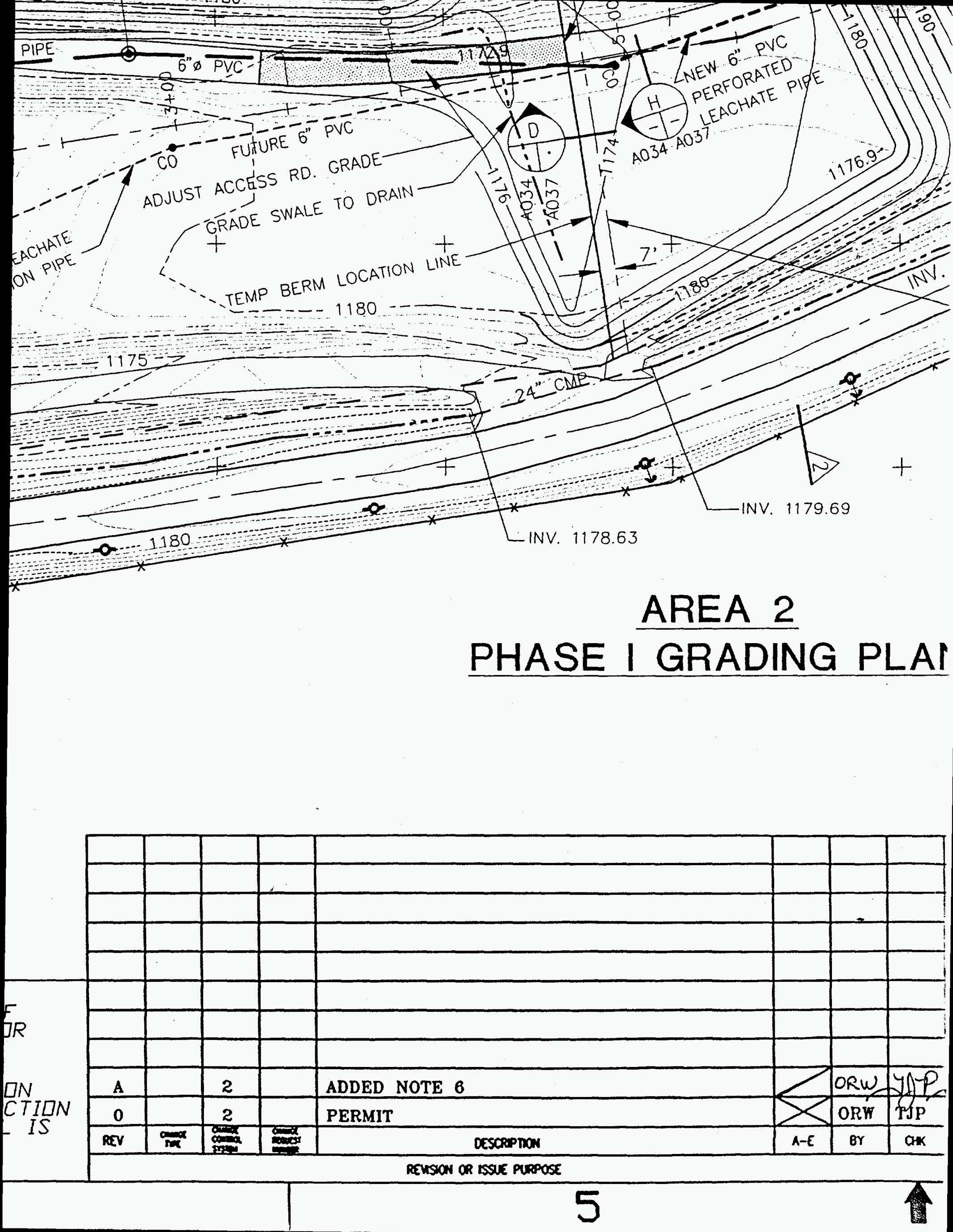




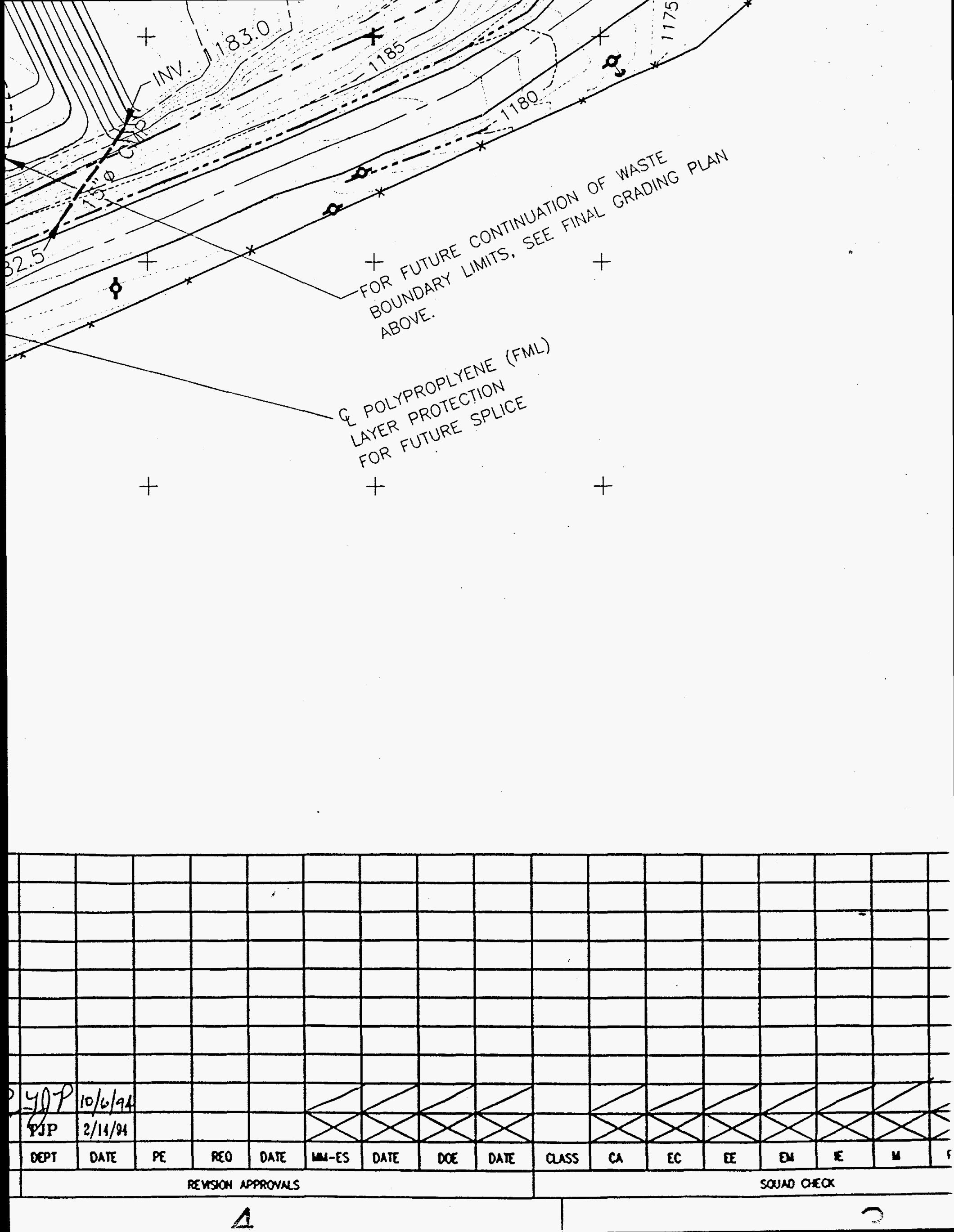




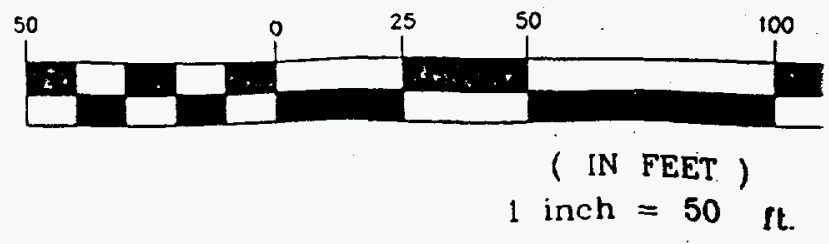

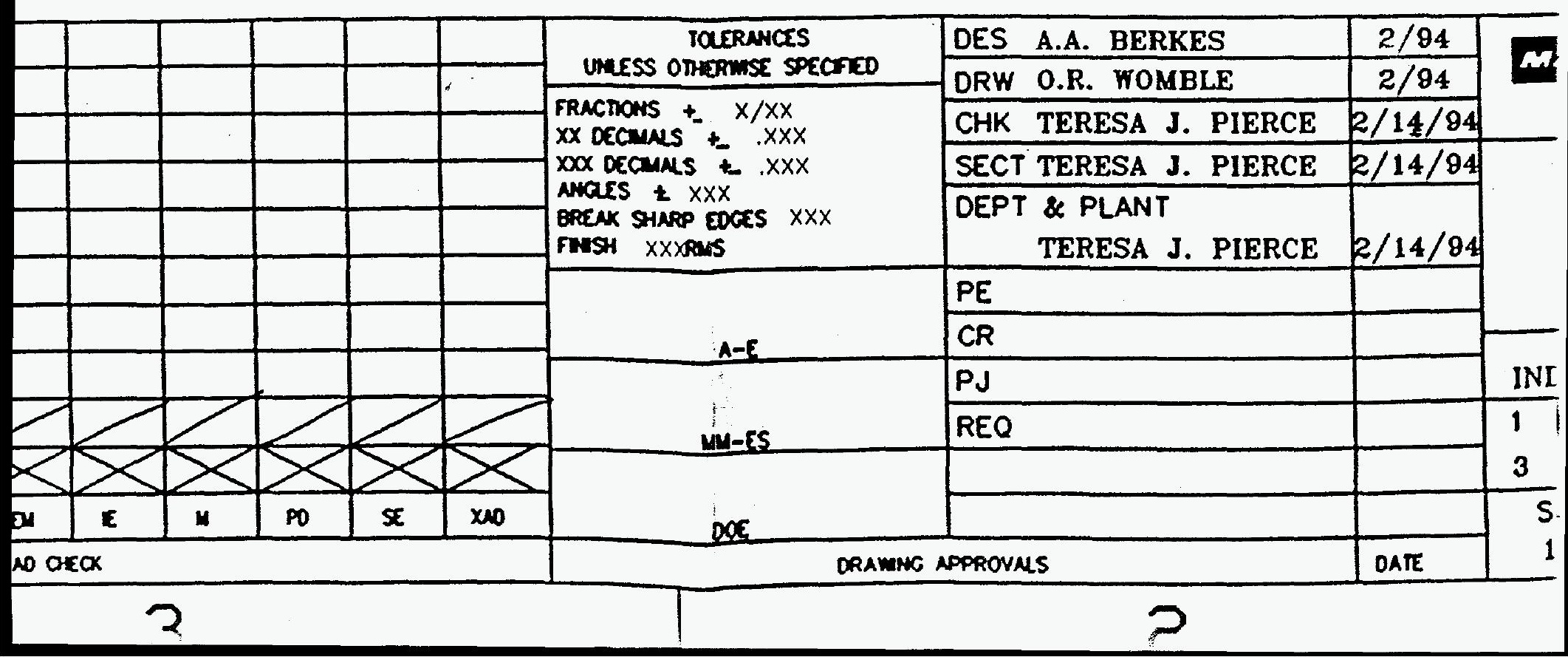




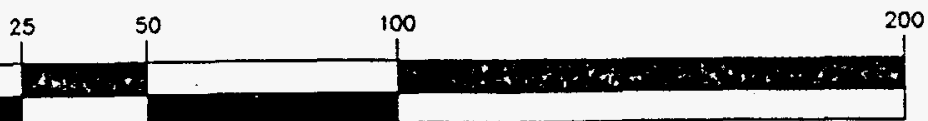

( IN FEET)

1 inch $=50 \mathrm{ft}$.

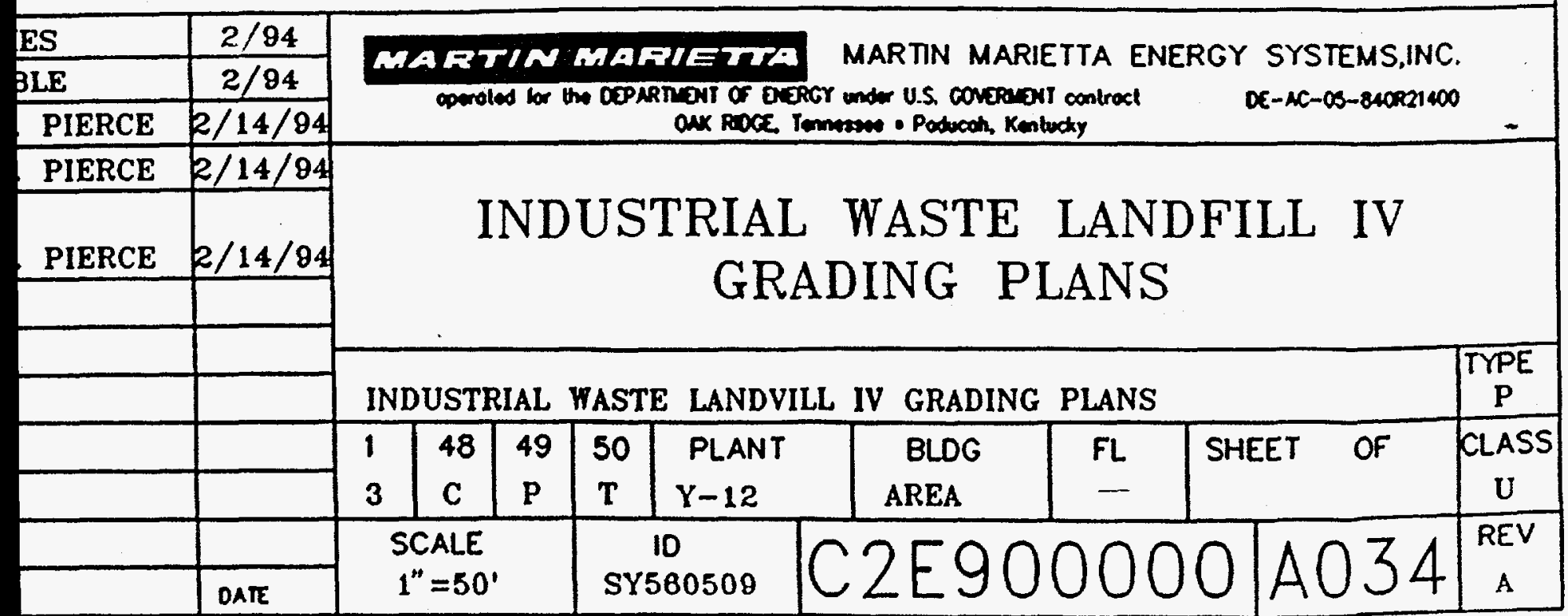


ATTACHMENT B

THE FOLLOWING ARE PAGES TO BE REPLACED, DELETED, OR ADDED

Y/WM-187:

Main Document Cover Page to replace the old page

Y/TS-399/R1, "DESIGN AND OPERATING PROCEDURE FOR THE Y-12 INDUSTRIAL WASTE LANDFILL IV:

Cover Page to replace the old page

Page 9 to replace Page 9

Page 15 to replace Page 15

Delete Appendix D

Specification Sections of YIWM-187:

Table of Content to replace the old page

Page 02220-8 to replace Page 02220-8

Page 02598-8 to replace Page 02598-8

Page 02598-12 to replace Page 02598-12

Design Drawing:

C2E-900000-A034 Rev A to replace C2E-900000-A034 Rev 0 